\title{
Chromosome 20
}

National Cancer Institute

\section{Source}

National Cancer Institute. Chromosome 20. NCI Thesaurus. Code C13216.

The designation for each member of the third smallest human autosomal chromosome pair. Chromosome 20 spans around 63 million base pairs and represents between 2 and $2.5 \%$ of the total DNA in normal diploid cells. 